\author{
KATARZYNA ZIMNOCH \\ ORCID: 0000-0002-4237-9675 \\ Uniwersytet w Białymstoku

\section{KSIĘGOZBIÓR KSIĘDZA STEFANA BARANOWICZA, PROBOSZCZA PARAFII KNYSZYŃSKIEJ (1711-1729) W DIECEZJI WILEŃSKIEJ}

\begin{abstract}
Stan badań i źródła. Ksiądz Stefan Baranowicz i parafia knyszyńska. Księgozbiór księdza Stefana Baranowicza — tematyka, autorzy książek. Księgozbiory kościelne w Knyszynie — duchownego i parafialny.
\end{abstract}

SŁOWA KLUCZOWE: księgozbiory historyczne, księgozbiory kościelne (parafialne, duchownych) w XVIII wieku, diecezja wileńska, Knyszyn (województwo podlaskie), ks. Stefan Baranowicz, proboszcz parafii knyszyńskiej (1712-1729)

\title{
WSTĘP
}

Paulina Buchwald-Pelcowa (2005, s. 341), badaczka piśmiennictwa staropolskiego, konstatowała: „,enna jest każda wiadomość o katalogach, inwentarzach czy choćby rejestrach ksiąg z okresu staropolskiego. Wydobyto ich już sporo, ale wiele jeszcze pracy należy włożyć w odszukiwanie i opublikowanie dalszych spisów książek". Są one cennym źródłem informacji o tym, co czytali kiedyś ludzie, czym się interesowali oraz do jakich tekstów mieli dostęp.

Jest więc kilka powodów, dla których warto przyjrzeć się księgozbiorowi księdza Stefana Baranowicza z pierwszej połowy XVIII wieku. Po pierwsze, nie był on jeszcze w całości obiektem badań. Po drugie, jest przykładem księgozbioru duchownego z historycznej diecezji wileńskiej, z dekanatu knyszyńskiego, który leżał na jej zachodnich obrzeżach. Jego udokumentowanie i analiza pozwolą na zapoznanie się z jego zawartością, a w przyszłości na dokonanie porównań $\mathrm{z}$ innymi bibliotekami duchownych. Po trzecie, oprócz zachowanego w księdze 
wizytacyjnej z 1727 roku spisu książek proboszcza zachował się rejestr biblioteki parafialnej z tego samego okresu, co daje możliwość porównania zawartości obu księgozbiorów i udzielenia odpowiedzi na pytanie, co mogło wpływać na ich charakter, czy zbiory te się uzupełniały, czy też dublowały. Ponadto następny spis biblioteki parafialnej, który powstał cztery lata później, w 1731 roku, ukazuje, czy książki duchownego zostały, tak jak chciał ksiądz Baranowicz, włączone do księgozbioru parafialnego. Można również poszukiwać odpowiedzi na pytanie, czy różnorodność wyznaniowa i etniczna badanego obszaru mogła wpływać na zbiory duchownego - w źródłach znajdujemy wszak informacje, że w czasach jego probostwa w Knyszynie kilka rodzin muzułmańskich (Tatarów) z pobliskiej miejscowości dokonało konwersji na chrześcijaństwo.

\section{STAN BADAŃ I ŹRÓDŁA}

Tematyka bibliotek parafialnych i księgozbiorów duchownych była już wielokrotnie podejmowana w literaturze naukowej. Zajmowano się zarówno bibliotekami w parafiach, dekanatach, archidiakonatach, diecezjach, jak i prywatnymi księgozbiorami księży (Żmuda, 2016). Zwracano uwagę na potrzebę badań nad dziejami i funkcjami takich bibliotek (Zahajkiewicz, 2002; Biernacka, Dubiński, 2000). Analizowano ich zbiory, kreśląc ich tematykę, ale także poszukiwano dzieł polskich autorów, literatury patrystycznej, greckiej, łacińskiej, o treściach świeckich lub książek poszczególnych autorów, próbowano nawet rozpoznać ich rolę w rozwoju czytelnictwa (Domański, 2007). W badaniach tych starano się odtworzyć prywatne księgozbiory duchownych, a ksiądz Jan Kracik (1976) przyglądał się różnicom między bibliotekami parafialnymi a prywatnymi zbiorami duchownych. Bardzo często studia nad księgozbiorami kościelnymi traktowano jako asumpt do przedstawienia fragmentu dziejów kultury intelektualnej danej epoki.

Powstały również prace na temat bibliotek parafialnych i duchownych na terenie historycznej diecezji wileńskiej. Zaprezentowano stan badań i źródła do ich poznania oraz ogólną charakterystykę poradników religijnych i traktatów teologicznych w wybranych księgozbiorach kościelnych tej diecezji (Zimnoch, 2012; Gąsowska, 2018). Na podstawie inwentarzy z XVII i XVIII wieku zbadane zostały biblioteki - parafialna w Zabłudowie oraz prywatna księdza Tomasza Rafała Płońskiego, proboszcza tamtejszej parafii w latach 1688-1701 (Zimnoch, 2007a, b). Niedawno poruszone zostały zagadnienia związane $\mathrm{z}$ księgozbiorem parafialnym w Knyszynie. Badania te oparto na danych z inwentarza z 1731 roku. (Zimnoch, 2019). Zajmowano się również bibliotekami parafialnymi na tym obszarze w dwudziestoleciu międzywojennym (Szot, 2004/2005, 2005/2006). 
Księgozbiór księdza Baranowicza nie został jeszcze zbadany. Informacje o książkach należących do tego duchownego znalazły się w aktach wizytacyjnych z 1727 i 1731 roku, przechowywanych w Archiwum Archidiecezjalnym w Białymstoku w zespole akt archidiakonatu białostockiego (sygn. 2.1.21) ${ }^{1}$. Zostały one sporządzone w języku łacińskim. Spisy książek knyszyńskiego proboszcza zamieszczono po inwentarzu biblioteki kościelnej („Inventarium Librorum Ecclesiae"). Należy też podkreślić, że zbiór ten duchowny chciał ofiarować na rzecz swojego kościoła, pod warunkiem, że będzie mógł z niego korzystać i nim dysponować do końca swego życia. Z omawianych dokumentów kościelnych widać, że wizytatorzy interesowali się spisami książek. W 1731 roku w dekretach reformacyjnych (zarządzeniach wizytatora) znalazły się wyjaśnienia, dlaczego brakuje niektórych książek, kto je obecnie posiada, co się z nimi stało.

W tym miejscu warto wspomnieć o księgozbiorach w parafii knyszyńskiej. Książki gromadzone były tam niemal od początków powstania kościoła w XVI wieku. Ze źródeł wynika, że były to księgi liturgiczne, księgozbiory parafialne oraz prywatne książki duchownych. Z badań nad szesnastowiecznymi testamentami wiadomo, że własną biblioteczkę miał wikariusz knyszyński Andrzej Neapolitanus. W jego testamencie z 1594 roku wymieniono: Biblię, postylle w języku polskim, brewiarz, mszał krakowski, stare kazania w rękopisie, Catechismus Catholicus Fryderyka Nausei, Lombardica Historia Jakuba de Voragine oraz zbiory kazań, przede wszystkim autorstwa Gabriela Biela, Roberta Carracciolo, Bertranda de la Toura. Neapolitanus zapisał je kościołowi. W samym akcie nie ma podanej nazwy miejscowości, ale badacz ostatniej woli wspomnianego duchownego, Łukasz Gołaszewski (2012, s. 258-260), twierdził, że chodziło o kościół knyszyński. Z kolei pierwsze informacje o tamtejszej bibliotece parafialnej odnajdujemy w księdze wizytacyjnej z 1633 roku$^{2}$, w której wspomniano o kilku książkach, przede wszystkim liturgicznych i pomocach homiletycznych. Lepiej jest rozpoznany księgozbiór parafialny z 1731 roku (Zimnoch, 2019, s. 129-138). $\mathrm{W}$ inwentarzu $\mathrm{z}$ tego roku wymieniono 53 pozycje. Był to więc zbiór średniej wielkości. Zawierał on Pismo Święte, konkordancje i komentarze biblijne oraz zbiory kazań i literaturę teologiczną. Najliczniejsze były pomoce homiletyczne - Sermones, Postilla, Conciones, Homiliae. Zgromadzono dość duży zbiór gotowych kazań na różne okresy roku liturgicznego, a także cykle de sanctis, quadragesimale (na okres Wielkiego Postu), pro festis (na święta), in dominicas (na niedziele). Znalazły się $\mathrm{w}$ nim również pozycje $\mathrm{z}$ zakresu prawa kościelnego (zbiory przepisów kanonicznych, postanowienia soborowe i synodalne, listy pa-

1 „Descriptio Status Ecclesiae... 1727”; „Descriptio Status Ecclesiae... 1731”.

2 „Acta visitationis ecclesiarum... 1633”. 
sterskie) i cywilnego (Promptuarium statutorum omnium et constitutionum Regni Poloniae Pawła Szczerbica), filozofii, historii oraz książki, które mogły służyć szkole parafialnej, ale nie są zidentyfikowane, jak „liber mathematicus”, „liber phisicorum"3. Przeważały starsze wydania publikacji, a ich autorami w dużej mierze byli zakonnicy spoza Rzeczypospolitej. Jednak można zauważyć pewne ślady wpływów wileńskich w postaci książek jezuitów związanych z Wilnem: Piotra Skargi, Jakuba Olszewskiego, a także dominikanina Augustyna Rakiewicza. Dokładna znajomość inwentarza z 1731 roku może pomóc w prześledzeniu losów księgozbioru księdza Stefana Baranowicza.

\section{KSIĄDZ STEFAN BARANOWICZ I PARAFIA KNYSZYŃSKA}

Ksiądz Stefan Baranowicz był proboszczem w Knyszynie w latach 1712-1729. Do parafii przybył już po pożarze kościoła w 1710 roku, czyli wydarzeniu, które znacząco wpłynęło na życie parafii, a ze źródłoznawczego punktu widzenia przyczyniło się do zniszczenia wielu cennych ruchomości z okresu szesnastowiecznej fundacji świątyni. Jej odbudowa była jednym z najważniejszych zadań, z którymi musiał mierzyć się nowy pleban.

W knyszyńskich metrykach kościelnych ksiądz Baranowicz występuje już od 1711 roku jako ,coadiutor”, wiadomo też, że przybył on z Nowego Dworu, gdzie był altarzystą. Wówczas w Knyszynie proboszczem był jeszcze ksiądz Remigiusz Hipolit Szczawiński. Rok później ksiądz Baranowicz został proboszczem i funkcję tę pełnił przez 16 lat. Historycy zwracają uwagę, że jako kapłan był gorliwy, o czym ma świadczyć osobiste udzielanie większości sakramentów (Cyganek, 2012, s. 155). Za jego czasów kilku mieszkańców wsi Tatary, leżącej pod byłą twierdzą tykocińską, przeszło z islamu na chrześcijaństwo, co zostało zarejestrowane w kronice parafialnej oraz źródłach metrykalnych.

Parafia knyszyńska jest jedną z najstarszych w tej części historycznej diecezji wileńskiej. Jej początki, podobnie jak samego Knyszyna, związane są z osobą Mikołaja Radziwiłła, wojewody wileńskiego i kanclerza wielkiego litewskiego, który w 1520 roku ufundował kościół parafialny. Świątynia miała nosić wezwania Narodzenia Najświętszej Maryi Panny, świętych Jana Ewangelisty i Andrzeja Apostołów oraz świętej Apolonii. Niestety kościół uległ zniszczeniu. W latach 1579-1600 wzniesiono murowany kościół szpitalny pod wezwaniem Wszystkich Świętych. Przyczyniły się do tego starania Jana Zamoyskiego, starosty knyszyńskiego i kanclerza wielkiego koronnego. $Z$ czasem na nową świątynię przeniesiono wezwanie świętego Jana Apostoła i Ewangelisty oraz beneficjum zrujnowanego

3 Szkoła parafialna w Knyszynie istniała już na początku XVII wieku (Chodorowski, 1993, s. 38-43; Malesińska, 2006, s. 60). 
kościoła parafialnego. Niestety również ta budowla uległa zniszczeniu, do czego przyczynił się zwłaszcza wspomniany już pożar z pierwszej połowy XVIII wieku. Dzisiejszy kościół pod wezwaniem świętego Jana Apostoła i Ewangelisty w Knyszynie zachował się do naszych czasów w dość zmienionym w stosunku do pierwotnego stanie. W omawianym czasie, pierwszej połowie XVIII wieku, parafia knyszyńska obejmowała następujące miejscowości: miasto Knyszyn i wsie Grądy, Boguszewo, Chraboły, Rudę, Górę, Rekle, Długołękę, Pęskie, Zastocze, Wodziłłówkę, Jaskrę, Czechowiznę oraz Krypno, gdzie znajdował się kościół filialny.

W okresie przedrozbiorowym Knyszyn stanowił siedzibę dekanatu. Był to jeden z najbardziej wysuniętych na zachód dekanatów diecezji wileńskiej. W XVIII wieku w jego skład wchodziły parafie w: Białymstoku, Choroszczy, Chodorówce (Suchowoli), Janowie, Juchnowcu (z altarią), Kalinówce, Knyszynie (z filią w Krypnie), Korycinie, Niewodnicy, Turośni (z altarią), Wasilkowie i Zabłudowie. Był to więc ważny ośrodek kościelny na tych terenach.

Warto też zwrócić uwagę na dobra knyszyńskie, które syn wspomnianego Mikołaja Radziwiłła, również Mikołaj (biskup żmudzki), zapisał królowi Zygmuntowi II Augustowi. Zarządzała nimi w imieniu małoletniego dziedzica jego matka, Bona Sforza, którą historycy nazywają założycielką Knyszyna. Na jej polecenie Aleksander Chodkiewicz, wojewoda nowogródzki i starosta knyszyński, w latach 1537-1540 przeprowadził pomiarę włóczną. Z czasem starostwo knyszyńskie (z włączonym do niego goniądzkim) stało się jednym z bogatszych w całej Rzeczpospolitej i było w rękach przedstawicieli znakomitych rodów (Zamoyskich, Ossolińskich, Orsettich, Gnińskich, Czapskich, Krasińskich i Raczyńskich). Zygmunt August upodobał sobie tę część Podlasia, leżącą na trasie między Wilnem a Krakowem. Z badań wynika, że w latach 1545-1572 król przebywał w Knyszynie 19 razy, spędzając w nim 500 dni, tutaj także zmarł 7 lipca 1572 roku. Architekt królewski Hiob (Job) Bretfus zaprojektował kompleks pięciu drewnianych budynków, składających się na dwór królewski. Zygmunt II August nadał Knyszynowi prawa miejskie magdeburskie dosyć późno, bo dopiero 18 października 1568 roku (Maroszek, 2018). W pobliskim Tykocinie władca miał zamek, sprowadził tam część swojego księgozbioru, którym zajmował się starosta tykociński i wasilkowski, pisarz Łukasz Górnicki (Hartleb, 1928; Kawecka-Gryczowa, 1988). Według nielicznych wzmianek niektóre książki znajdowały się również w knyszyńskim dworcu królewskim. Po śmierci ostatniego przedstawiciela dynastii Jagiellonów starostwo knyszyńskie znalazło się w rękach kanclerza Jana Zamoyskiego. W 1580 roku wydał on tutaj panegiryk na cześć swojej zmarłej żony Krystyny, córki Mikołaja Krzysztofa Radziwiłła „Czarnego" - Christina Radivila vel de illustri uxore Principes d. Georgium episcopum Vilnensem d. Nicolaum Christophorum, summum Magni Ducatus Lithuaniae, Praefectum Caunensem, d. Stanislaum Radivilos fratres, Olicae et Nesvisiae duces T. Gisii sereniss. regis Poloniae 
secretarii (Kawecka-Gryczowa, 1971, s. 355-376). Druk ten wyszedł z knyszyńskim adresem wydawniczym w tak zwanej drukarni latającej (filia krakowskiej oficyny Mikołaja Szarfenbergera, działająca w latach 1577-1581). W ten sposób Knyszyn zapisał się w historii kultury książki. Niestety najazdy obcych wojsk, zwłaszcza podczas potopu szwedzkiego, a następnie w trakcie wojny północnej w pierwszym dwudziestoleciu XVIII wieku, oraz epidemie i pożary zahamowały rozwój miasta i jego okolic.

Knyszyn i ziemie, które wchodziły w skład tamtejszej parafii, były zamieszkane wówczas przez ludność chrześcijańską (katolicy, unici; należy zauważyć, że w XVI wieku, a potem, w XIX stuleciu, żyli tam również ewangelicy i prawosławni), muzułmańską (Tatarzy) oraz żydowską. Najliczniejszą mniejszością była ta ostatnia. Początki jej osadnictwa w Knyszynie sięgają XVI wieku i są związane z funkcjonowaniem w mieście dworu królewskiego. W 1672 roku mieszczanie knyszyńscy uzyskali przywilej „,de non tolerandis Judaeis”, dlatego też od tego momentu ludność żydowska zamieszkiwała w całości dzielnicę Ogrodniki, gdyż nie obejmowało jej prawo miejskie, a tamtejsze grunty należały do dworu knyszyńskiego (królewszczyzna). W 1719 roku nastąpiło złagodzenie ograniczeń osadnictwa Żydów w mieście; ponadto obowiązek uiszczania kozubalca na rzecz kościoła parafialnego został zastąpiony dorocznymi zryczałtowanymi opłatami wnoszonymi do kościoła na Boże Narodzenie, Wielkanoc i Zielone Świątki. Pod koniec XVIII wieku w Knyszynie żyło już ponad 200 Żydów, stanowiąc prawie 19\% mieszkańców miasteczka (Leszczyński, 1989, s. 10-11). Tatarzy również byli osadzani na tych terenach w XVI-XVII wieku. Najczęściej zamieszkiwali pod zamkami lub przy przeprawach rzecznych, by strzec bezpieczeństwa władcy i jego urzędników. Pod twierdzą tykocińską osadził ich Olbracht Marcinowicz Gasztołd. Tatarzy mieszkali przede wszystkim w okolicach Knyszyna i Tykocina, we wsiach Tatary i Kruszyn oraz w osadach Białobrzeskie, Rekle, Kołodzież, Kolesniki, Długołęka i Niewiarowo (Grygajtis, 2003, s. 147). W późniejszym okresie mniejszość ta zasymilowała się z miejscową ludnością lub też przeniosła się w okolice większych skupisk społeczności mahometańskiej, na przykład do Kruszynian.

\section{KSIĘGOZBIÓR KSIĘDZA BARANOWICZA - TEMATYKA I AUTORZY KSIĄŻEK}

W omawianym spisie książek należących do duchownego wymieniono 34 pozycje, w tym przy trzech wskazano, że były to publikacje dwutomowe. Odnotowano je według formatów, co może świadczyć o tym, że spisywano je po kolei z półek, gdzie były ułożone według wielkości (in folio - siedem pozycji, w tym obok dwóch tytułów widnieje informacja, że są to pozycje w dwóch tomach; in quarto 
— osiem, w tym jedna pozycja w dwóch tomach; in octavo - dwie książki: libri minores - dwanaście woluminów). Ponadto pod tym spisem wymieniono jeszcze kilka dzieł: Biblię w dużym formacie, ale z dopiskiem, że niedawno została odzyskana, oraz Żywoty świętych starego i nowego zakonu Piotra Skargi i książki w formacie in quarto autorstwa Wojciecha Tylkowskiego i Jana Drewsa. W obrębie poszczególnych formatów książki nie były uszeregowane alfabetycznie ani według autora, ani według tytułu; co najwyżej w kilku przypadkach można dopatrywać się grupowania ich według tematyki, ale biorąc pod uwagę przewagę literatury teologicznej, nie można $\mathrm{z}$ tego wyciągać dalej idących wniosków. Poszczególne pozycje nie zostały ponumerowane, wymieniono książki jedną obok drugiej, nie zawsze oddzielając poszczególne zapisy kropką czy przecinkiem. Być może nie były to wszystkie książki księdza Baranowicza. Brakuje jednak informacji źródłowych pozwalających uzupełnić listę jego księgozbioru.

Opisy publikacji były dosyć lakoniczne, najczęściej odnotowywano ich skrócony tytuł $\mathrm{i}$ autora, nie podawano natomiast daty i miejsca wydania. W przypadku 22 pozycji można określić autora i tytuł książki; pięciu — jedynie autora; kolejnych pięciu — tematykę; dwóch nie udało się zidentyfikować. Pod niektórymi zapisami może się kryć kilka dzieł. Większość książek była w języku łacińskim. Zdarzało się, że wymieniono jedynie autora, na przykład „Busembaum” lub enigmatycznie wskazywano temat książki: „Liber medicus”. Rejestr książek swą niekompletnością i pobieżnym zapisem nie odbiega od innych spisów tego typu z badanego okresu. Na 34 pozycje udało się zidentyfikować 26 z nich, zaś pozostałe jedynie zakwalifikować do działu tematycznego.

W zbiorach księdza Baranowicza znajdowały się Pismo Święte, literatura teologiczna pasterska, ascetyczna, polemiczna, hagiograficzna, homiletyczna, a także publikacje z zakresu retoryki. Na uwagę zasługują pomoce dla duchownych oraz kilka książek o tematyce świeckiej.

Zdecydowanie najwięcej było tytułów z zakresu teologii i filozofii oraz praktycznych podręczników i pomocy służących księżom w formacji duchowej, a przede wszystkim w pracy duszpasterskiej. Wśród nich znalazło się dzieło flamandzkiego autora Jakoba Marchanta (1585-1648), zatytułowane Hortus pastorum et concionatorum i zaliczane do teologii pastoralnej; ze względu na formę przekazu uznawano je za bardzo przydatne w pracy duszpasterskiej i kaznodziejskiej. O dużej popularności tego utworu świadczą także liczne wydania zarówno w XVII wieku, jak i na początku kolejnego stulecia. Podobnie było ze znajdującymi się w omawianym zbiorze: podręcznikiem teologii moralnej Methodus expeditae confessionis, napisanym przez włoskiego jezuickiego teologa Tommasa Tamburiniego (1591-1675), dziełem hiszpańskiego jezuity Juana Eusebia Nieremberga (1595-1658) pod tytułem Doctor Evangelicus ex variis selectisque concin- 
natus opusculis oraz utworem franciszkanina Bernarda Mercatora (1600-1699), noszącym tytuł Nucleus Catecheticus.

W zbiorach księdza Baranowicza znajdowała się też książka autorstwa niemieckiego jezuity Hermanna Busenbauma (Busembauma, 1600-1668). Niestety nie podano tytułu tego utworu. Prawdopodobnie chodzi o Medulla theologiae moralis - bardzo rozpowszechniony podręcznik teologii moralnej. Było to nader popularne kompendium, przydatne zwłaszcza dla spowiedników. Książka ta od 1650 roku do drugiej połowy XVIII wieku miała niemal 200 wydań, z czego sześć w Polsce: w Lublinie, Gdańsku, Braniewie i Sandomierzu. Można ją też często odnaleźć w spisach bibliotek kościelnych. Ksiądz Baranowicz posiadał także książkę polskiego jezuity Mikołaja Łęczyckiego (Nicolausa Lanciciusa, 1574-1653), autora wielu dzieł filozoficznych. Większość jego dzieł została opublikowana w dwutomowym zbiorze Opuscula spiritualia (Antwerpia 1650); prawdopodobnie właśnie ta pozycja była częścią omawianego księgozbioru.

Wśród posiadanych przez knyszyńskiego plebana dzieł teologicznych i filozoficznych znalazła się praca teologa ascetycznego, mariologa, a także penitencjarza i kanonika katedry włocławskiej Michała Rychalskiego (1654-1688), zatytułowana Quadriga sacerdotum ad caelum (łaciński tytuł dzieła można przetłumaczyć jako: „Kwadryga kapłanów do Nieba, czyli przeznaczenie kapłańskie ukazane przez cztery rzeczy ostateczne"). Została ona wydana przez cystersów w Oliwie w 1686 roku, a następnie dwukrotnie w Wilnie (w 1703 i 1707 roku) oraz w Krakowie (w 1705 i 1747 roku). Był to traktat o czterech rzeczach ostatecznych, czyli śmierci, Sądzie Bożym, piekle (potępieniu) i niebie (chwale). Badacze zaliczają go do literatury określanej jako „quattuor hominum novissima” (K. Koczur-Lejk, 2019; Kowzan, 2003). Według nich prace z tego zakresu miały uświadamiać odbiorcom konsekwencje obranego przez nich stylu życia doczesnego. Pamięć o „czworakiej wieczności” miała być dla chrześcijanina najlepszą zachętą do pokuty i poprawy. Zatem mogła to być przydatna w pracy duszpasterskiej i formacji duchowej księdza publikacja.

W omawianym zbiorze była książka polskiego jezuity Wojciecha Tylkowskiego (1625-1695). Niestety nie można ustalić jej tytułu, ponieważ odnotowano: „sine titulo polonicus”. Tylkowski pisał po łacinie i polsku. Skróconą i uproszczoną wersją najsłynniejszego jego dzieła Philosophia curiosa były Uczone rozmowy wszystka $w$ sobie prawie zawierające filozofija (Warszawa 1692) — możliwe, że o nią właśnie chodzi.

Bardzo ciekawie prezentował się zbiór publikacji stanowiących praktyczną pomoc w pracy duszpasterskiej. Niewątpliwie służyły temu praca Giovanniego Battisty Bernardina Possevina (1552-1622) pod tytułem Praxis curae pastoralis czy też książka poświęcona zagadnieniom związanym z religijnymi aspektami śmierci autorstwa jezuity Philippa Serviusa (inaczej: Bouchy'ego, 1576-1657), 
nosząca tytuł Amicus Fidelis usque ad mortem. Należy zwrócić uwagę na cenione ówcześnie dzieło paulina Grzegorza Terleckiego (1597-1660), Confessio et instructio idiotae, sive modus excipiendi confessiones sacrametales (Kraków 1655), będące praktycznym podręcznikiem na temat sprawowania sakramentu pokuty i kierownictwa duchowego. Badacze tej książki zwracają uwagę, że jej autor starał się wychodzić naprzeciw ludziom prostym, niewykształconym, nieraz życiowo zagubionym, a także dzieciom.

W tym miejscu warto zwrócić uwagę na Distractiones itinerantium (w późniejszym tłumaczeniu na język polski: Dystrakcje podróżnych pobożne, uczone $i$ ucieszne) jezuity Jana Drewsa (1646-1710). Publikacja ta jest modlitewnikiem i zbiorem medytacji dla podróżnych. Zawarte są w niej teksty modlitw i medytacji, pieśni religijnych oraz pouczeń co do zachowania się w drodze - na przykład cierpliwość, ostrożność w wypowiadaniu własnych sądów itp. Większość z nich nawiązywała do zaleceń duszpasterskich okresu potrydenckiego (ścisłe i szczegółowe polecenia, zakazy, nakazy). Miały one skłaniać do „nabożnych rozmyślań”, chronić przed niebezpieczeństwami, jakie mogły przydarzyć się w podróży. Badacz tej książki, Bogdan Rok, zwraca uwagę, że wówczas mógł to być także informator krajoznawczy na temat wielu krajów europejskich, a także stwierdza, że autor poradnika miał przychylny stosunek do podróżowania. Oczywiście informacje te były podawane przy okazji, a tom ten miał wspierać medytacje na typowe tematy natury religijnej (Rok, 1996). Pouczenia te powstały na przełomie XVII i XVIII wieku. Po raz pierwszy wydano je po łacinie w Braniewie w 1701 roku (następnie w 1708, 1720 i 1727 roku), raz opublikowano je w Lublinie (1735 rok), a dopiero później w Częstochowie w latach 1744 i 1751 — wówczas również w języku polskim. Proboszcz parafii knyszyńskiej miał któreś z pierwszych wydań tej pozycji. Książka ta musiała być popularna, a niewielki format wszystkich edycji sprawiał, że mogła być wykorzystywana jako podróżny modlitewnik.

Może nieco zdziwić stosunkowo mała liczba pozycji z zakresu homiletyki. Były to kazania jezuitów: wspomnianego już Juana Eusebia Nieremberga Homiliae catenate, a także Homiliae catholicae Juana de Cartagena (1563-1618), Jeremiasa Drexela (Hieremiasa Drexeliusa lub Drechsela, 1581-1638), autora licznych prac homiletycznych i teologicznych, oraz francuskiego dominikanina Guillaume’a Pepina (1465-1533). Na uwagę zasługują zwłaszcza kazania o tematyce maryjnej, ponieważ kościołowi knyszyńskiemu podlegała świątynia filialna w Krypnie, gdzie od dawna szerzył się kult maryjny ${ }^{4}$. Były to Homiliae catholicae

${ }^{4}$ Historia kultu maryjnego w Krypnie sięga czasów fundatora kościoła knyszyńskiego, Mikołaja Mikołajewicza Radziwiłła, który szczególną rewerencją otaczał kult Matki Boskiej. Według historyków było to konsekwencją uznania, że jej wstawiennictwu zawdzięczał on zwycięstwo nad Tatarami w bitwie pod Kleckiem 5 sierpnia 1506 roku (święto Najświętszej Maryi Panny Śnieżnej). Jako przykłady można podać jego fundacje: kościół pod wezwaniem świętego Jerzego i Matki 
Cartageny oraz prawdopodobnie homilie Guillaume'a Pepina. Lakoniczny zapis przy jego nazwisku wskazuje na kazania, a był on autorem licznych zbiorów, $w$ tym między innymi maryjnych: Conciones... 3, Rosarium aureum B. Mariae virgini.

Na pewno w zakresie homiletyki pomocne były praca polskiego jezuity Baltazara Dankwarta (1629-1699), zatytułowana Breve directorium concionatoris apostolici i omawiająca cele i zadania wymowy kościelnej, a także dzieła jezuitów: Żywoty świętych... Piotra Skargi (1536-1612), Concionator historicus Michaela Pexenfeldera (1613-1685) oraz Apologi morales S. Cyrilli Balthasara Corderiusa (1592-1650), znanego z licznych przekładów i objaśnień dzieł ojców i pisarzy Kościoła greckiego.

Na uwagę zasługuje słynna książka dominikanina Abrahama Bzowskiego (1567-1637), Annales Ecclesiastici, będąca kontynuacją Roczników kościelnych kardynała Cezara Baroniusza (zmarłego w 1607 roku). Były to dzieje kościelne obejmujące lata 1198-1572, swego rodzaju historia Kościoła powszechnego tego okresu. Badacze twórczości tego zakonnika zwracają uwagę, że roczniki te, podobnie jak wcześniejsze dzieło Baroniusza, „stanowiły część ofensywy propagandowej Kościoła w okresie wojen religijnych" (Pater, 1979, s. 78; Szczucki, 1981, s. 35-46).

Bardzo interesująco prezentowała się ówczesna literatura polemiczna znajdująca się w omawianym zbiorze. Wyróżniają się tutaj prace jezuity Jerzego Gengella (1657-1727). Był on autorem książek skierowanych głównie przeciwko protestantom, krytykował luteranizm, kalwinizm, jansenizm oraz ateizm. Ksiądz Baranowicz posiadał dwa utwory tego zakonnika: Admiranda Jansenisimi oraz Eversio atheismi. Obie prace zostały wydane u jezuitów w Braniewie — pierwsza w 1715 roku, druga rok później. Ponadto spośród dzieł z zakresu teologii polemicznej w zbiorach knyszyńskiego plebana znalazła się książka księdza Wojciecha Wijuk-Kojałowicza (1609-1677); prawdopodobnie mowa tu o pracy Colloquia Theologi cum Ministro, de dissidiis in rebus fidei inter Catholicos et Calvinistas. Ksiądz Baranowicz posiadał również dziełko włoskiego jezuity Roberta Bellarmina (1542-1621) De potestate Summi Pontificis. Należy zauważyć, że tego typu literatura była obecna także w zbiorach innych duchownych, na przykład w diecezji chełmińskiej, na co zwrócił uwagę przy okazji swoich badań ksiądz Bogusław Dygdała. Jednocześnie odnotował on spadek jej popularności na przestrzeni kilkudziesięciu lat: w 1670 roku stanowiła ona 3,9\% księgozbiorów tamtejszego duchowieństwa, w 1700 roku - 1,9\%, a następnie już tylko $0,8 \%$. Fakt ten ksiądz Dygdała tłumaczy w następujący sposób: „w miarę upływu czasu duchowni byli więc coraz mniej zainteresowani kontrowersjami, co jednak nie budzi żadnego

Boskiej Śnieżnej dla zakonu karmelitów trzewiczkowych w Wilnie, a na terenie Podlasia: kościoły Narodzenia w Rajgrodzie i Knyszynie, Zwiastowania w kaplicy na zamku w Goniądzu oraz Dobrzyniewie, Niepokalanego Poczęcia w Kalinówce, Wniebowzięcia w Waniewie (Wróbel, 2019, s. 41). 
zdziwienia, gdyż wobec wyraźnego triumfu działań kontrreformacyjnych i zarazem petryfikacji stosunków wyznaniowych w diecezji nie było po prostu takiej potrzeby" (Dygdała, 2009, s. 159-160).

$Z$ literatury świeckiej zidentyfikowano jedynie dwie pozycje. Jedną z nich była książka z zakresu anatomii Andrzeja z Kobylina, zwanego Glaberem (1500-1572), zatytułowana Problemata Aristotelis. Gadki z pisma wielkiego philosopha Aristotela, y też inszych mędrcow tak przyrodzoney iako y lekarskiey nauki... i wydana w Krakowie w 1535 roku. Drugą z nich opisano jedynie jako „Liber medicus” — być może w 1731 roku odnotowano ją w spisie księgozbioru jako: „Chirurgia Institutio”.

W omawianym zbiorze znalazły się książki 24 osób, z czego trzy były autorami dwóch prac — byli to jezuici Jan Drexell, Juan Eusebio Nieremberg i Jerzy Gengell. Najwięcej było dzieł pisarzy siedemnastowiecznych (20), z niewielką przewagą tych tworzących w pierwszej połowie stulecia (jedenaście pozycji). Pojedyncze prace zostały napisane przez autorów żyjących w XVIII wieku (dwie publikacje) lub też wcześniej, w XVI wieku (również dwa tytuły). Jedenastu twórców książek z omawianego zbioru pochodziło z Rzeczypospolitej, zaś trzynastu z państw Zachodniej Europy. Nie widać tutaj wielkiej przewagi któregoś z krajów: czterech autorów pochodziło z Niemiec, po trzech z Niderlandów i Włoch, dwóch z Hiszpanii i jeden z Francji. Do drugiej połowy XVII wieku dominowali pisarze zagraniczni, natomiast od połowy tegoż stulecia uwidacznia się przewaga polskich twórców.

Były to książki autorstwa duchownych, w większości zakonników (21) i duchownych diecezjalnych (trzy pozycje). Najwięcej autorów dzieł z omawianego księgozbioru reprezentowało Towarzystwo Jezusowe — aż 17 publikacji, z czego siedem pochodziło z Rzeczypospolitej, a dziesięć z zagranicy. Polscy jezuici to: Piotr Skarga, Mikołaj Łęczycki, Wojciech Tylkowski, Baltazar Dankwart, Wojciech Wijuk-Kojałowicz, Jerzy Gengell, Jan Drews. Z Niemiec pochodziło trzech jezuickich autorów: Jeremias Drexell, Hermann Busenbaum, Michael Pexenfelder; z Włoch ta sama liczba twórców: Robert Bellarmin, Tommaso Taburini, Giovanni Battista Bernardino Possevino (bratanek legata papieskiego Antonia Possevina); po dwóch z Hiszpanii: Juan Eusebio Nieremberg, Juan de Cartagena; oraz z Niderlandów: Philippe Servius, Balthasar Cordier. Byli również przedstawiciele innych zakonów. Wśród nich znalazło się dwóch dominikanów, jeden pochodzący z Polski - Abraham Bzowski; drugi z Francji — Guillaume Pepin. Zakon paulinów reprezentował jeden autor - Grzegorz Terecki; podobnie miała się sytuacja z franciszkanami, do którego to zakonu należał Bernardinus Mercator. Wśród autorów pochodzących z duchowieństwa diecezjalnego byli Michał Rychalski wikariusz, penitencjarz, kanonik i psałterzysta katedry we Włocławku; Andrzej Glaber — ksiądz, lekarz, pisarz, profesor Akademii Krakowskiej, kanonik kolegiaty świętej Anny w Krakowie; oraz Jacob Marchant — dziekan i proboszcz w Couvien (obecnie Belgia). 
Niestety w spisie książek nie podano adresów wydawniczych. Trudno więc określić w większości przypadków miejsce ich publikacji, tym bardziej że część $\mathrm{z}$ nich była wydawana wielokrotnie w różnych drukarniach. Były to drukarnie funkcjonujące zarówno na terenie Rzeczypospolitej, jak i w Europie Zachodniej. W Polsce były one zlokalizowane przede wszystkim w Wilnie (Drukarnia Akademicka) i Braniewie (Drukarnia Jezuitów), w krajach niemieckich zaś w Kolonii (Coloniae Agrippinae; drukarnie: Antona Botzera, Joannesa Busaeusa Gymnichów — „Pod Jednorożcem”- i Petera Henninga) i Monachium (oficyny Johanna Wagnera i Johanna Gelderna), we Francji natomiast w Lyonie (Lugduni; Joannis Baudrand, François Comba) a we Włoszech w Rzymie (Tipografia Zanetti).

Warto zwrócić uwagę, że wielu polskich autorów związanych było z Wilnem. Byli oni profesorami (niektórzy także rektorami) tamtejszej Akademii (rektorzy: Piotr Skarga, Wojciech Wijuk-Kojałowicz, Baltazar Dankwart; wykładowcy: Mikołaj Łęczycki, Wojciech Tylkowski, Jan Drews). Tylkowski przez dwa lata był także regensem seminarium papieskiego w Wilnie, założonego z inicjatywy papieża Grzegorza XIII w 1582 roku, które miało kształcić księży dla pracy misyjnej wśród protestantów oraz prawosławnych. Z kolei Baltazar Dankwart, pochodzący ze znanej wileńskiej rodziny lutniczej, był prokuratorem prowincji litewskiej w latach 1679-1683. Wiele książek z omawianego zbioru było wydawanych w dzisiejszej stolicy Litwy (między innymi te autorstwa M. Rychalskiego, B. Dankwarta, P. Skargi, W. Wijuk-Kojałowicza). Oczywiście w kilku przypadkach nie były to jedyne wydania.

\section{KSIĘGOZBIORY KOŚCIELNE W KNYSZYNIE - DUCHOWNEGO I PARAFIALNY}

W aktach wizytacyjnych z 1727 roku wymieniono zarówno zbiór książek proboszcza, księdza Stefana Baranowicza, jak i biblioteki parafialnej. Dzięki temu można przyjrzeć się obu księgozbiorom, spróbować je porównać oraz odnieść się do wniosków wysnutych przez księdza Jana Kracika, który porównywał biblioteczki parafialne i prywatne zbiory duchownych z dekanatu Nowa Góra w diecezji krakowskiej.

Zbiór książek księdza Baranowicza, jak wykazano wyżej, liczył 34 odnotowane pozycje. $Z$ kolei w bibliotece parafialnej spisano 37 tytułów. Oba księgozbiory były więc podobnych rozmiarów.

W knyszyńskiej bibliotece parafialnej w 1727 roku znajdowały się Pismo Święte, komentarze biblijne, w tym często wówczas spotykane prace autorstwa niderlandzkiego zakonnika Dionizego Kartuza. Największą część księgozbioru stanowiły pomoce homiletyczne - Sermones, Postilla, Conciones, Homiliae. 
Księża parafialni mieli do dyspozycji spory zestaw gotowych kazań na różne okresy roku liturgicznego. Wśród autorów omawianych książek znaleźli się polscy duchowni, w tym: dominikanin Fabian Birkowski, jezuita Jakub Olszewski, bernardyn Antoni Stefanowicz czy kanonik krakowski, polihistor, polemista Szymon Starowolski. Przeważali jednak zagraniczni autorzy kazań, między innymi dominikanin Guillermus (Guilelmus) Parisiensis, hiszpańscy jezuici Jan Ossorius i Kacper Sanchez, franciszkanie Johann Ferus (Johann Wild), Henryk Helmezjusz oraz Filip Diez, a także francuski duchowny Nicolaus Denisse. Podobnie było $\mathrm{w}$ przypadku literatury z zakresu teologii — znalazły się tam książki autorstwa duchownych z Europy Zachodniej: jezuitów Franciszka z Toledo, Jana Polanco, Ludwika de Ponte i Emmanuela Sa, dominikanina Sylwestra Mazzoliniego, franciszkanina błogosławionego Anioła Carlettiego z Chivasso (Anioła de Clavasio), kartuza Dionizego Kartuza oraz kanonika regularnego Marcina Aspilcuety (zwanego Nawarskim). Oprócz traktatów teologicznych gromadzono wszelkiego rodzaju kompendia i opracowania, między innymi Summa confessorum Jana z Fryburga. Miały one służyć nieustannej formacji religijnej i intelektualnej duchownych oraz pomagać w konkretnym wykorzystaniu wiedzy w codziennej pracy duszpasterskiej. W omawianym spisie figurowały dzieła świętego Tomasza z Akwinu i głośne publikacje kardynała Stanisława Hozjusza. Obecne były także prace z zakresu prawa kościelnego (między innymi zbiory przypisów kanonicznych, postanowienia soborowe i synodalne, a także listy pasterskie) i cywilnego (książka autorstwa prawnika, sekretarza królewskiego, wykładowcy Akademii Zamoyskiej Pawła Szczerbica Promptuarium statutorum omnium et constitutionum Regni Poloniae oraz praca Flosculi practici Teodora Zawackiego, prawnika, znanego pisarza rolniczego, autora publikacji z zakresu prawa procesowego oraz poradnika rolniczego). Ponadto znajdowały się tam tytuły, które mogły służyć szkole parafialnej.

Analiza zawartości obu księgozbiorów pozwala wysnuć kilka wniosków. $\mathrm{W}$ bibliotece parafialnej zdecydowanie dominowała literatura kaznodziejska, która była słabo reprezentowana w prywatnym zbiorze duchownego. Mogło to oczywiście wynikać z faktu, że proboszcz w tym zakresie korzystał ze zbiorów parafii. W swojej biblioteczce posiadał on pomoce dotyczące retoryki, wymowy, medytacji, a ponadto również publikacje wspierające pracę duszpasterską, w tym głoszenie kazań. W księgozbiorze parafialnym były także książki na temat ustawodawstwa kościelnego i świeckiego, zaś w zbiorze prywatnym nie odnaleziono prac z tego zakresu. $Z$ kolei w bibliotece duchownego było zdecydowanie więcej literatury polemicznej. Widać więc, że księgozbiór parafialny miał odpowiadać na zapotrzebowania parafii, a ten należący do proboszcza był bardziej nastawiony na formację duchową duszpasterza. 
W zbiorach księdza Baranowicza było zdecydowanie więcej książek polskich autorów. Jak wykazano wyżej, w księgozbiorze prywatnym reprezentowanych było jedenastu polskich pisarzy (na 24 wszystkich ustalonych autorów), a w bibliotece parafialnej jedynie siedmiu Polaków spośród wszystkich 25 autorów. Mogło to także wynikać $\mathrm{z}$ faktu, że w księgozbiorze parafialnym niemal połowa (dwunastu) twórców książek pochodziła z XVI wieku, a pięciu nawet z okresu wcześniejszego. Jedynie ośmiu autorów żyło w XVII wieku i w tym okresie zaczyna być widoczna lekka przewaga twórców pochodzących i żyjących w Polsce.

Co ciekawe i ważne, w tych biblioteczkach nie powtarzają się żadne pozycje oprócz Biblii. Może to świadczyć o tym, że proboszcz Baranowicz, przebywający w Knyszynie już od 1711 roku, dobrze znał miejscowy księgozbiór parafialny i w związku z tym budował swoje prywatne zbiory w sposób zaplanowany. Księgozbiory więc się nawzajem uzupełniały.

Należy zwrócić uwagę na ustawodawstwo kościelne, w którym polecano duchownym zaopatrywanie się w książki liturgiczne, podręczniki kaznodziejskie, Biblię, kanony penitencjalne itp. ${ }^{5} \mathrm{~W}$ trosce o dobry poziom przekazywania wiernym prawd wiary ordynariusze wskazywali konkretne dzieła, które miały pomóc w pracy katechetycznej i przygotowywaniu homilii (Kracik, 2000, s. 247; Pelczar 1896, s. 76-77). W ustawach synodu wileńskiego z 1602 roku w celu głoszenia Słowa Bożego i administrowania sakramentów zalecano publikacje Osoriusa, Wujka, Skargi, Stapletona, Powodowskiego, Compendium Navarri, Aphorismos confessariorum Emmanuela Sa, Missale Romanum, Catechismum Canisii vel Ledesmae lithuanice translatu (Sawicki, 1948, s. 38). Zalecenia te powtórzono w czasie synodu z 1611 roku, dodając do spisu proponowanych książek Methodum ad iuvandi morientes (Sawicki, 1948, s. 38, 50). Większość z tych prac znajdowała się w księgozbiorze parafialnym, w zbiorze prywatnym z tej listy odnotowano natomiast jedynie pracę Piotra Skargi.

Można też spróbować odpowiedzieć na pytanie, czy w omawianych knyszyńskich księgozbiorach — duchownego i parafialnym — tak jak w badanych przez księdza Jana Kracika zbiorach, księgozbiór osobisty był tym podstawowym, bardziej aktualnym, służącym proboszczowi, zaś biblioteki parafialne stawały się niekiedy instytucjonalnym antykwariatem, a także ustalić, co działo się później $\mathrm{z}$ księgozbiorem duszpasterza.

Ksiądz Kracik, badając księgozbiory parafialne i prywatne księży, stawiał sobie następujące założenie: „Za podstawowy należy przyjąć księgozbiór osobisty. Brak świeżych tytułów w urzędowych bibliotekach plebańskich świadczy o ich charakterze: stanowiły one w rzeczywistości rodzaj jakiegoś instytucjonalnego

${ }^{5}$ Ustawodawstwo kościelne na ten temat przedstawił ksiądz Tomasz Moskal (2005, s. 53-66). Zob. też: Wójcik, 1963, s. 30; Zahajkiewicz, 2002, s. 12; Litak, 1969, s. 365. 
antykwariatu, gdzie składano używane książki i skąd je zabierano". Twierdził on także, że „duszpasterz posługiwał się zwykle książką własną, którą po latach zapisywał czy pozostawiał kościołowi. Jeśli dana pozycja wzbudzała zainteresowanie następcy, ten korzystał z niej, przy czym nierzadko zapomniał dość łatwo, że jest tylko jej użytkownikiem a nie posiadaczem" (Kracik, 1976, s. 270).

Jak to wyglądało w omawianych księgozbiorach knyszyńskich? Niestety nie da się sprawdzić daty wydania na podstawie adresu wydawniczego druków, ponieważ w obu przypadkach go nie podano. Można się posłużyć powyższymi informacjami na temat lat życia autorów książek z badanych biblioteczek. Oczywiście nie należy tego robić jedynie metodą statystyczną, bo w zbiorach mogą się znajdować prace doktorów Kościoła czy też książki autorstwa pisarzy starożytnych. Jednak w omawianych księgozbiorach niewiele było takich pozycji. Ze wspominanych analiz dotyczących życia twórców prac jednoznacznie wynika, że zdecydowanie więcej dzieł autorów bardziej współczesnych księdzu Baranowiczowi znajdowało się w jego prywatnej bibliotece.

Można także prześledzić fragmenty dziejów tych księgozbiorów. Knyszyński proboszcz ofiarował swoje książki parafii pod warunkiem, że może z nich korzystać i dysponować nimi do końca życia. Informacja ta została zapisana w aktach wizytacyjnych kościoła z 1727 roku. Cztery lata później, podczas kolejnej wizytacji, w księgozbiorze parafialnym oprócz 25 książek zarejestrowanych w 1727 roku znalazło się jedynie osiem publikacji należących do księdza. Były to Biblia, kazania Juana Cartageny i Guillaume'a Pepina, praca ascetyczna Philippa Serviusa, dwa dzieła Jerzego Gengella, pomoc dla duchownych autorstwa Giovanniego Battisty Bernardina Possevina oraz prawdopodobnie pozycja odnotowana jako „liber medicus”. Nie wiadomo, co się stało z pozostałymi książkami — trudno je odnaleźć w źródłach. Niemniej jednak warto zwrócić uwagę na zapis w dekrecie wizytacyjnym, w którym na pytanie o brakujące sprzęty kościelne, w tym książki, odpowiedziano, że część z nich została zniszczona przez odchodzącego z funkcji komendarza kościoła w Knyszynie księdza Wojciecha Dawidowskiego, który ponadto nie oddał dzieł z biblioteki knyszyńskiej ${ }^{6}$. Być może niektóre pozycje $\mathrm{z}$ badanego zbioru powędrowały razem ze wspomnianym duchownym na jego nową parafię w Sokolanach. W Knyszynie posługę pełnili także inni księża i niewykluczone, że w 1731 roku oni także korzystali z tej biblioteczki. J. Kracik (1976, s. 270) stwierdził, że przechodzenie woluminów ze zbiorów kościelnych do prywatnych (i odwrotnie) było dosyć powszechnym zjawiskiem.

Ponadto należy pamiętać, że książki, służąc latami do pracy duszpasterskiej, ulegały zniszczeniu na skutek ciągłego ich wykorzystywania, a niekiedy zostały celowo lub nieumyślnie unicestwione. W wielu przypadkach o istniejących histo-

6 „Descriptio Status Ecclesiae... 1731”, k. 7v. 
rycznych bibliotekach parafialnych można się dowiedzieć jedynie z zachowanych protokołów wizytacji kanonicznych parafii (Skrzyniarz, 2000, s. 415-416).

J. Kracik (1976, s. 254) wskazywał na nietrwałość księgozbiorów parafialnych. W omawianym przypadku również jest widoczne to zjawisko. Spośród 37 pozycji odnotowanych w księgozbiorze parafialnym w 1727 roku cztery lata później pozostało jedynie 25 książek. Ubyło więc co najmniej dwanaście dzieł. Jeszcze gorzej wyglądała sytuacja księgozbioru prywatnego księdza Baranowicza, przekazanego parafii. Tylko jedna czwarta jego zbiorów ostała się we wskazanej bibliotece. Z akt wizytacji, która miała miejsce sto lat później — w 1828 roku — dowiadujemy się, że „fundusz kościoła parafialnego knyszyńskiego żadnej biblioteki nie ma. Księgi, jakie się znajdują, te są własnością plebana" (Wróbel, 2019, s. 168). Niestety nie wymieniono zawartości księgozbioru duchownego.

\section{ZAKOŃCZENIE I WNIOSKI}

Badany księgozbiór księdza Stefana Baranowicza jest przykładem prywatnej biblioteki duchownego z okresu staropolskiego. Nie był to duży zbiór, liczył tylko 34 pozycje. Jednak należy zwrócić uwagę, odwołując się do prac Pauliny Buchwald-Pelcowej (2005, s. 341), że zainteresowanie badacza powinna budzić nie wielkość biblioteczki, a raczej dobór książek wchodzących w jej skład. Zauważalne jest zainteresowanie knyszyńskiego proboszcza różnymi kierunkami teologii i współczesną mu literaturą polemiczną. Duży wpływ na to miał zapewne wielowyznaniowy charakter obszaru, na którym funkcjonowała parafia — zresztą było to zjawisko charakterystyczne dla Podlasia w tamtym okresie. Ksiądz był zainteresowany także praktycznymi pomocami dla duszpasterstwa parafialnego. Autorzy książek znajdujących się w badanym księgozbiorze to duchowni zakonni i diecezjalni z terenów Rzeczypospolitej i krajów Europy Zachodniej. Znaczną część biblioteki stanowiły dzieła autorów, którzy tworzyli w ciągu 80 lat po soborze trydenckim. Wiele $\mathrm{z}$ tych publikacji było popularnych $\mathrm{w}$ tamtym okresie, o czym świadczą ich liczne wydania. Nie był to przypadkowy dobór książek służył formacji i pracy duszpasterskiej oraz poszerzał horyzonty księdza Baranowicza, a jednocześnie był on zgodny z nauką Kościoła katolickiego.

Można stwierdzić, że duchowny dobrze znał zawartość swojej i parafialnej biblioteki. Świadczą o tym przemyślana selekcja księgozbioru i niedublowanie prac znajdujących się już w bibliotece parafialnej. Ponadto fakt, że duchowny, przekazując własny księgozbiór kościołowi knyszyńskiemu, zastrzegł sobie możliwość korzystania z depozytu do końca swojego życia, może świadczyć o tym, że doceniał on znaczenie zebranych książek i wracał do ich lektury. Poznanie biblioteczki księdza Stefana Baranowicza daje też możliwość wyrobienia sobie poglądu na sprawę źródeł inspiracji intelektualnej i formacyjnej duchownych badanego okresu. 


\section{BIBLIOGRAFIA}

\section{ŹRÓDŁA}

„Descriptio Status Ecclesiae Knyszynensis in Palatinatu Podlachiae Dioecesis Vilnensis ad futuram Visitationem Anno 1727", k. 3v-4, Archiwum Archidiecezji Białostockiej (dalej: AAB), Akta archidiakonatu białostockiego, sygn. 2.1.21.

„Descriptio Status Ecclesiae Knyszynensis in Palatinatu Podlachia Dioecesis Vilnesis Ad futuram Visitationem Anno 1731", k. 4v-5, AAB, Akta archidiakonatu białostockiego, sygn. 2.1.21. „Acta visitationis ecclesiarum dioecesis Vilnensis, per illustrem et admodum reverendum Dominum Gasparum Zaliwski, canonicum Vilnensem S.R. Missionis Secretarium, authorem cominissionis illustrissimi et reverendissimi domini, domini Abraham Woyna, Dei et Apostolicae sedis gratia Episcopi Vilnensis celebratae... 1633", k. 187-190, Biblioteka Uniwersytetu Wileńskiego, Dział Rękopisów, F.57-53-40.

\section{OPRACOWANIA}

Biernacka, A., Dubiński, M. (2000). Zarys historii bibliotek parafialnych w Polsce. Archiwa, Biblioteki i Muzea Kościelne, 73, 9-21.

Buchwald-Pelcowa, P. (2005). Inwentarz biblioteki Jana Kazimierza Grabskiego z 1691 r. W: P. Buchwald-Pelcowa, Historia literatury i historia ksiązki. Studia nad ksiażka i literatura od średniowiecza po wiek XVIII (ss. 341-358). Kraków: Towarzystwo Autorów i Wydawców Prac Naukowych „Universitas”.

Chodorowski, E. (1993). Od szkolnictwa parafialnego do powszechnego i średniego w Knyszynie i jego okolicach. Białostocczyzna, 3, 38-43.

Cyganek, K. (2012). Kronika parafialna kościoła knyszyńskiego. Knyszyn: Knyszyńskie Towarzystwo Regionalne im. Zygmunta Augusta.

Domański, T. (2007). Udział duchowieństwa diecezji kieleckiej w rozwoju czytelnictwa i bibliotek parafialnych na przełomie XIX i XX wieku. Nasza Przeszłość, 107, 225-245.

Dygdała, B. (2009). Biblioteki parafialne w diecezji chełmińskiej w XVII i XVIII wieku. Czasy Nowożytne, 22, 145-161.

Gąsowska, M. (2018). Poradniki religijne oraz traktaty teologiczne w wybranych bibliotekach parafialnych Diecezji Wileńskiej na podstawie wizytacji dekanalnej biskupa Ignacego Jakuba Massalskiego z lat 1782-1784. Bibliotekarz Podlaski, 1, 139-152.

Gołaszewski, Ł. (2012). Testament wikariusza knyszyńskiego Andrzeja Neapolitanusa z 1594 roku. Kwartalnik Historii Kultury Materialnej, 60(2), 258-260.

Grygajtis, K. (2003). Rozwój osadnictwa tatarskiego w Wielkim Księstwie Litewskim do końca XV wieku. Piotrkowskie Zeszyty Historyczne, 5, 95-151.

Hartleb, K. (1928). Bibljoteka Zygmunta Augusta. Studjum z dziejów kultury królewskiego dworu. Lwów: Towarzystwo Miłośników Książki.

Kawecka-Gryczowa, A. (1988). Biblioteka ostatniego Jagiellona. Pomnik kultury renesansowej. Wrocław: Zakład Narodowy im. Ossolińskich.

Kawecka-Gryczowa, A. (1971). Dzieje „drukarni latającej”. Działalność i wędrówki. Rocznik Biblioteki Narodowej, 355-376.

Koczur-Lejk, K. (2019). Traktaty o czterech ostatecznych rzeczach człowieka w literaturze czeskiej XVI i XVII wieku. Zarys problematyki. Slavica Wratislaviensia, 168, 243-254.

Kowzan, J. (2003). „Quattuor hominum novissima”. Dzieje serii tematycznej czterech rzeczy ostatecznych w literaturze staropolskiej. Siedlce: Wydawnictwo Akademii Podlaskiej.

Kracik, J. (1976). Biblioteki parafialne a prywatne księgozbiory duchowieństwa. Dekanat Nowa Góra w XVII-XVIII wieku. Archiwa, Biblioteki i Muzea Kościelne, 32, 249-271. 
Kracik, J. (2000). Przeciw Reformacji. W: Kościól krakowski w tysiacleciu (ss. 178-250). Kraków: Znak.

Leszczyński, A. (1989). Z dziejów Żydów Podlasia (1487-1795). Studia Podlaskie, 2, 7-26.

Litak, S. (1969). Struktura i funkcje parafii w Polsce. W: J. Kłoczkowski (Red.), Kościół w Polsce, t. 2. Wieki XVI-XVIII (ss. 259-481). Kraków: Znak.

Malesińska, A. (2006). Knyszyn w XVIII wieku — życie codzienne małego miasta. Knyszyn: Knyszyńskie Towarzystwo Regionalne im. Zygmunta Augusta.

Maroszek, J. (Oprac.). (2018). Prawa i przywileje miasta Knyszyna 1509-1795. Monografia historyczna miasta Knyszyna z uwzględnieniem najnowszych badań archiwalnych. Knyszyn: Knyszyńskie Towarzystwo Regionalne im. Zygmunta Augusta.

Moskal, T. (2005). Biblioteki parafialne w archidiakonacie sandomierskim w XVIII w. Sandomierz: Wydawnictwo Diecezjalne.

Pater, J. (1979). Życie i twórczość Abrahama Bzowskiego O.P. (1567-1637). Nasza Przeszłość, 51, $55-87$.

Pelczar, J.S. (1896). Zarys dziejów kaznodziejstwa w Kościele katolickim, t. 1. Kaznodzieje greccy do IX, tacińscy do XVI wieku. Kraków: Spółka Wydawnicza Polska.

Rok, B. (1996). Jezuita Jan Drews (1646-1710) i jego modlitewnik dla peregrynantów. Saeculum Christianum. Pismo historyczno-spoleczne, 3(1), 219-227.

Sawicki, J. (1948). Concilia Poloniae. Źródta i studia krytyczne, t. 2. Synody diecezji wileńskiej $i$ ich statuty. Warszawa: Towarzystwo Naukowe Warszawskie.

Skrzyniarz, R. (2000). Księgozbiór parafialny w Bielanach według wizytacji z 1738 r. Archiwa, Biblioteki i Muzea Kościelne, 73, 415-416.

Szczucki, L. (1981). Reformacja protestancka w dziele Abrahama Bzowskiego. Odrodzenie i Reformacja $w$ Polsce, 26, 35-46.

Szot, A. (2004/2005). Biblioteki parafialne i prasa katolicka archidiecezji wileńskiej w okresie międzywojennym. Bibliotekarz Podlaski, 9/10, 99-108.

Szot, A. (2005/2006). O bibliotekach parafialnych słów kilka. Bibliotekarz Podlaski, 11/12, 52-57.

Wójcik, W. (1963). Archiwum i biblioteka kapituły w Sandomierzu. Archiwa, Biblioteki i Muzea Kościelne, 7, 5-41.

Wróbel, M. (2019). Wizytacja generalna kościoła i parafii w Knyszynie w 1828 r. W: A. Szot (Red.), Parafia w Knyszynie 1520-2020. Odkrywanie dziejów (ss. 139-188). Knyszyn: Gmina Knyszyn.

Wróbel, W. (2019). Działalność fundacyjna Mikołaja Mikołajewicza Radziwiłła na terenie dóbr goniądzko-rajgrodzkich w latach 1509-1521. W: A. Szot (Red.), Parafia w Knyszynie 15202020. Odkrywanie dziejów (ss. 19-46). Knyszyn: Gmina Knyszyn.

Zahajkiewicz, M. (2002). Funkcja i znaczenie biblioteki parafialnej lub klasztornej. Archiwa, Biblioteki i Muzea Kościelne, 77, 9-17.

Zimnoch, K. (2007a). Księgozbiory parafialne w Zabłudowie. Rocznik Zabłudowski, 1, 4-22.

Zimnoch, K. (2007b). Księgozbiór księdza Tomasza Rafała Płońskiego proboszcza parafii w Zabłudowie na przełomie XVII i XVIII wieku (w latach 1688-1701). W: J. Leończuk (Red.), Od księgoznawstwa przez bibliotekoznawstwo do nauki o informacji XXI wieku (ss. 117-130). Białystok: Książnica Podlaska im. Łukasza Górnickiego.

Zimnoch, K. (2012). Książka na pograniczu Korony i Litwy w epoce nowożytnej. Rekonesans badawczy. W: W.F. Wilczewski (Red.), Colloquia Collegii Suprasliensis, t. 1. Supraśl (ss. 87-111). Supraśl: Collegium Suprasliense.

Zimnoch, K. (2019). Z dziejów księgozbioru parafialnego w Knyszynie w XVIII w. W: A. Szot (Red.), Parafia w Knyszynie 1520-2020. Odkrywanie dziejów (ss. 129-138). Knyszyn: Gmina Knyszyn.

Żmuda, R. (2016). Bibliografia publikacji o bibliotekach kościelnych za lata 1945-2015. Łódź: Uniwersytet Medyczny. 


\title{
THE BOOK COLLECTION FROM FATHER STEFAN BARANOWICZ, THE PRIEST OF KNYSZYN PARISH (1711-1729) IN THE VILNIUS DIOCESE
}

\author{
Summary
}

The subject of the paper is the book collection of father Stefan Baranowicz, priest for the Knyszyn parish in the year 1712-1729. This book collection is an example of a private clerical library from the staropolskie (,old Polish”) period. The main sources for exploring this library are the visitational acts from 1727, currently stored in the Archdiocese Archives in Bialystok. For the purpose of comparison, the book collection of the local parish from the same period has been discussed. The size, subject matter and authorship of the books that comprise both collections. The research concludes that the parish book collection was meant to meet local parish needs, whereas the priest's private collection was more oriented towards the personal spiritual formation of clerics. In contrast to the parish library, the books collected by father Baranowicz tended towards being more contemporary, and included more works by Polish authors. The content of both collections did not overlap, and we can observe the transfer of books from church collections to private ones and vice versa, which would have been quite common at the time. The study and analysis of the collection of father Baranowicz gives the possibility of further comparative research of clerical book collections in the 1st half of the 18th century.

KEY WORDS: Historical book collections, parochial book collections (of the parish and the clergy) - 18th century, Vilnius diocese, Knyszyn (podlaskie voivodeship), father Stefan Baranowicz, priest of the Knyszyn parish (1712-1729) 